\title{
Cyclic uniaxial mechanical load enhances chondrogenesis through entraining the molecular circadian clock
}

Judit Vágó ${ }^{1}$; Éva Katona ${ }^{1}$; Roland Takács ${ }^{1}$; Róza Zákány ${ }^{1}$; Daan van der Veen ${ }^{2}$;

Csaba Matta ${ }^{1, *}$

${ }^{1}$ Department of Anatomy, Histology and Embryology, Faculty of Medicine, University of Debrecen, Debrecen, H-4032, Hungary

${ }^{2}$ Chronobiology, Faculty of Health and Medical Sciences, University of Surrey, Guildford, Surrey, GU2 7XH, United Kingdom

*Corresponding author: Csaba Matta - e-mail: matta.csaba@med.unideb.hu

Phone: +36-52-255-567

Running title: Mechanical stimuli entrain the circadian clock during chondrogenesis 
bioRxiv preprint doi: https://doi org/10.1101/2021.10.26.465847; this version posted October 26, 2021. The copyright holder for this preprint (which was not certified by peer review) is the author/funder, who has granted bioRxiv a license to display the preprint in perpetuity. It is made available under aCC-BY-NC-ND 4.0 International license.

Vágó et al. - Mechanical stimuli entrain the circadian clock during chondrogenesis

\section{Abstract}

Objective: The biomechanical environment plays a key role in regulating cartilage formation, but current understanding of mechanotransduction pathways in chondrogenic cells is still incomplete. Amongst the combination of external factors that control chondrogenesis are temporal cues that are governed by the cell-autonomous circadian clock. However, mechanical stimulation has not yet directly been proven to modulate chondrogenesis via entraining the circadian clock in chondroprogenitor cells.

Design: The purpose of this study was to establish whether mechanical stimuli entrain the core clock in chondrogenic cells, and whether augmented chondrogenesis caused by mechanical loading was at least partially mediated by the synchronised, rhythmic expression of the core circadian clock genes, chondrogenic transcription factors, and cartilage matrix constituents.

Results: We report here, for the first time, that cyclic uniaxial mechanical load applied for 1 hour for a period of 6 days entrains the molecular clockwork in chondroprogenitor cells during chondrogenesis in limb bud-derived micromass cultures. In addition to the several core clock genes, the chondrogenic markers $S O X 9, A C A N$, and $C O L 2 A 1$ also followed a robust sinusoidal rhythmic expression pattern. These rhythmic conditions significantly enhanced cartilage matrix production and upregulated marker gene expression. The observed chondrogenesis-promoting effect of the mechanical environment was at least partially attributable to its entraining effect on the molecular clockwork, as co-application of the small molecule clock modulator longdaysin attenuated the stimulatory effects of mechanical load.

Conclusions: Results from this study suggest that an optimal biomechanical environment enhances tissue homeostasis and histogenesis during early chondrogenesis through entraining the molecular clockwork.

(248 words in abstract) 
bioRxiv preprint doi: https://doi.org/10.1101/2021.10.26.465847; this version posted October 26, 2021. The copyright holder for this preprint (which was not certified by peer review) is the author/funder, who has granted bioRxiv a license to display the preprint in perpetuity. It is made available under aCC-BY-NC-ND 4.0 International license.

Vágó et al. - Mechanical stimuli entrain the circadian clock during chondrogenesis

\section{Keywords}

chondrogenesis; circadian rhythm; molecular clock; mechanical load; chondrochronology;

longdaysin

\section{Abbreviations}

CCG, clock-controlled gene; CKI, casein kinase I; DMMB, dimethyl-methylene blue; DMSO, dimethyl sulfoxide; ECM, extracellular matrix; IHH, Indian hedgehog; LDS, longdaysin; MS, mechanical stimulation; MSC, mesenchymal stem cell; RORE, retinoic acid-related orphan receptor response element; RQ, relative quantity; RSD, relative standard deviation; TTFL, transcriptional-translational feedback loop 
bioRxiv preprint doi: https://doi.org/10.1101/2021.10.26.465847; this version posted October 26, 2021. The copyright holder for this preprint (which was not certified by peer review) is the author/funder, who has granted bioRxiv a license to display the preprint in perpetuity. It is made available under aCC-BY-NC-ND 4.0 International license.

Vágó et al. - Mechanical stimuli entrain the circadian clock during chondrogenesis

\section{Introduction}

Cartilage is a specialised connective tissue with major structural and mechanical roles in the body. Articular cartilage is involved in load bearing, providing shape, cushioning and lubricating diarthrodial joints [1]. Given that chondrocytes only occupy $1-3 \%$ of the tissue volume in mature cartilage, the unique biomechanical properties of the tissue are attributable to the composition and organization of the extracellular matrix (ECM), which is a complex network of collagens, proteoglycans, other non-collagenous proteins, and constituent water [2]. The special architecture of the ECM provides cartilage with unique biomechanical properties in terms of compression, shear and tension.

During the complex process of chondrogenesis, chondroprogenitor mesenchymal cells differentiate into chondroblasts and then chondrocytes, which produce cartilage ECM in response to internal or external stimuli [3]. These stimuli include a combination of chemical, biological, and physical cues in the stem cell niche of progenitor cells, the specific combination and timing of which are essential for chondrogenesis [4]. One of the most important external factors relevant to articular cartilage is the biomechanical environment. External mechanical load of an appropriate magnitude and frequency is essential for maintenance of the mature articular cartilage phenotype [5]. The stimulatory effect of biomechanical forces on ECM synthesis by chondrocytes has been well documented [6]; dynamic loading of mature cartilage enhances the production of glycosaminoglycans, cartilage oligomeric matrix protein, and collagen type II [7]. Regular moderate physical activity has been shown to be necessary to maintain the healthy composition of articular cartilage ECM [8].

Biomechanical stimulation also plays a key role in regulating cartilage growth during the development of the skeletal system [6]. The importance of movement during embryonic chondrogenesis and joint formation has been demonstrated using paralysed chicken embryos $[6,9]$. Dynamic compressive load has been reported to stimulate epiphyseal cartilage growth 
bioRxiv preprint doi: https://doi.org/10.1101/2021.10.26.465847; this version posted October 26, 2021. The copyright holder for this preprint (which was not certified by peer review) is the author/funder, who has granted bioRxiv a license to display the preprint in perpetuity. It is made available under aCC-BY-NC-ND 4.0 International license.

\section{Vágó et al. - Mechanical stimuli entrain the circadian clock during chondrogenesis}

[10], and variations in mechanical loading of articular cartilage have been proposed to modulate cartilage thickness [11]. Both static and uniaxial cyclic compression have been reported to enhance the chondrogenic differentiation of embryonic limb bud-derived mesenchymal cells through the upregulation of collagen type II, aggrecan core protein, and the chondrogenic transcription factor Sox $9[12,13]$. Our group has documented the stimulatory effect of dynamic uniaxial mechanical load on chick limb bud-derived micromass cultures via the PKA/CREBSox9 and PP2A pathways [14]. However, despite the emerging results on the molecular mechanisms mediated by mechanical load, current understanding of the mechanotransduction pathways in chondrogenic cells is still generally lacking.

Amongst the combination of chemical, biological, and physical cues known to guide mesenchymal stem cell (MSC) differentiation, a temporal cue recently discovered to be involved in the process is governed by the circadian rhythm $[15,16]$. The molecular mechanisms that regulate the circadian clock in somatic cells rely on a network of autoregulatory transcriptional-translational feedback loops (TTFL), which drive the rhythmic expression patterns of the core clock components [17]. The primary TTFL is controlled by the transcription factors CLOCK and BMAL1 which, after forming a heterodimer, bind to regulatory elements within target core clock genes including period (PER1, PER2, and PER3) and cryptochrome (CRY1 and CRY2), as well as many clock-controlled genes (CCGs). PER and CRY proteins in turn multimerise and inhibit CLOCK/BMAL1 activity, thus blocking their own transcription [17]. The CLOCK:BMAL1 heterodimers also regulate the transcription of retinoic acid-related orphan nuclear receptors, REV-ERBs and RORs, which bind to retinoic acid-related orphan receptor response elements (ROREs) present in the BMAL1 promoter. REV-ERBs repress transcription of BMAL1, whereas RORs activate the transcription [17].

The $\sim 24$ hour period of the endogenous molecular clockwork is reset daily by external cues, known as Zeitgebers. Whilst exposure to direct sunlight is the primary factor in entraining 
bioRxiv preprint doi: https://doi.org/10.1101/2021.10.26.465847; this version posted October 26, 2021. The copyright holder for this preprint (which was not certified by peer review) is the author/funder, who has granted bioRxiv a license to display the preprint in perpetuity. It is made available under aCC-BY-NC-ND 4.0 International license.

\section{Vágó et al. - Mechanical stimuli entrain the circadian clock during chondrogenesis}

the main circadian clock in the hypothalamus, peripheral tissues are not light sensitive in mammals. Peripheral clocks thus entrain to systemic cues driven by the central clock, such as growth factors and hormones (e.g. glucocorticoids) but various rhythms in their local environment also have a well-established role as Zeitgeber [17]. An emerging entrainment mechanism for the circadian clock is mechanical stimulation. Rhythmic mechanical loading of the chordotonal organs can synchronise the Drosophila circadian clock [18]. The mechanical environment of the epithelial stem cell niche controls the amplitude of the oscillation of the molecular clock [16]. Although the specific molecular mechanisms whereby mechanical load entrains the circadian clockwork are not fully explored, CLOCK has been found to be mechanosensitive in chondrocytes [19]. Mechanical stress loading has been shown to affect the circadian rhythm in developing skeletal muscle through modulating core clock gene expression $[20]$.

Being necessary for maintaining healthy cartilage [21], recent results indicate that the clock genes can directly influence MSC differentiation, including adipogenesis [22] and chondrogenesis [15].

Recently, interactions between the biological clock proteins and developmental pathways in chondrogenesis has become an emerging area of research. Indian hedgehog (IHH), a central regulator of chondrocyte differentiation, and its receptor Ptch1, are directly controlled by the circadian clock in chondrocytes [23, 24]. Key transcription factors relevant to chondrogenesis including Sox6 and Sox 9 are probably also controlled by the biological clock during chondrocyte differentiation $[15,25]$. The expression of several genes involved in cartilage ECM turnover including ACAN, MMP13, and COL2A1 have been shown to oscillate over the course of a day in chondrocytes [26]. However, cyclic mechanical stimulation has not yet been proven to enhance chondrogenesis via entraining the circadian clock in chondroprogenitor cells. Here we report for the first time that cyclic uniaxial mechanical load 
bioRxiv preprint doi: https://doi.org/10.1101/2021.10.26.465847; this version posted October 26, 2021. The copyright holder for this preprint (which was not certified by peer review) is the author/funder, who has granted bioRxiv a license to display the preprint in perpetuity. It is made available under aCC-BY-NC-ND 4.0 International license.

Vágó et al. - Mechanical stimuli entrain the circadian clock during chondrogenesis

applied for 1 hour for a period of 6 days synchronises the molecular clockwork during chondrogenesis in limb bud-derived micromass cultures, and may enhance chondrogenic differentiation via entraining the circadian rhythm.

\section{Materials and Methods}

\subsection{Experimental setup}

Micromass cell cultures undergoing spontaneous in vitro chondrogenic differentiation were set up using embryonic chicken limb bud-derived chondroprogenitor cells. Cultures received 60 min of uniaxial dynamic loading every 24 hours for 6 days using our custom-made bioreactor [14]. Samples were then collected every 8 hours between 24- and 72-hours poststimulation. Control, unstimulated cultures from the same biological replicates received a medium change with fresh DMEM containing $10 \%$ FBS at time point 0 on culturing day 6 , and harvested at the same time points as the colonies receiving mechanical load. The expression patterns of the core clock genes (BMAL1, PER2, PER3, CRY1, CRY2, REV-ERB) and osteochondrogenic marker genes (SOX6, SOX9, RUNX2, COL2A1, ACAN) were studied using qRTPCR and were subjected to cosine analysis. The effects of the circadian clock regulator longdaysin, in combination with mechanical load, on chondrogenesis were evaluated using histological assessment and by monitoring the expression levels of chondrogenic markers using qRT-PCR. Analyses were performed on 3 biological replicates $(N=3)$. The workflow is summarised in Fig. 1. 


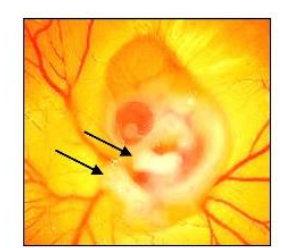

Distal limb buds of 4-day-old chick embryos $N=3$

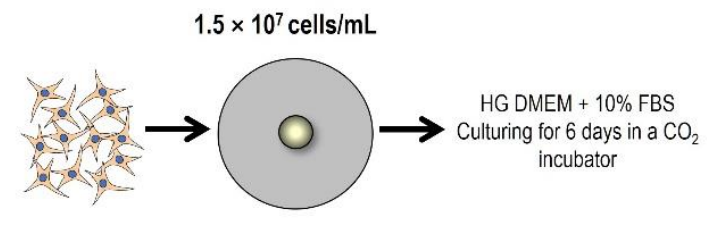

Chondroprogenitors Micromass cultures

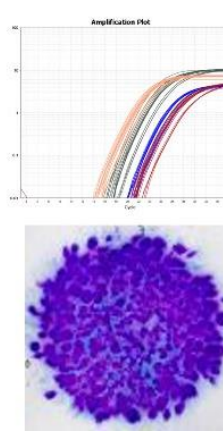

Total RNA isolation \& RT-qPCR from 3 biological replicates

+ - LDS treatment

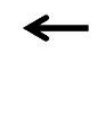

Metachromatic staining

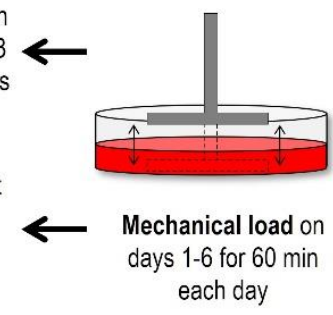

Figure 1. Experimental workflow. HG DMEM, high glucose-containing DMEM media; LDS, longdaysin

\subsection{Primary micromass cell cultures}

Chondrifying micromass cell cultures were established from early-stage chicken embryos as previously described [15]. Briefly, distal parts of forelimbs and hindlimbs of embryos were isolated, pooled and dissociated in trypsin-EDTA (Merck, Darmstadt, Germany) for $1 \mathrm{~h}$. The dissociated limb buds were then filtered through a $20-\mu \mathrm{m}$ pore size cell strainer (Merck) to generate a single-cell suspension of chondrogenic mesenchymal cells. Cells were then pelleted and resuspended in high glucose DMEM culture medium (Lonza, Basel, Switzerland) supplemented with 10\% FBS (Lonza) at a concentration of $1.5 \times 10^{7}$ cells $/ \mathrm{mL}$. $100 \mu \mathrm{L}$ droplets were inoculated into 6-well plates (Eppendorf, Hamburg, Germany). After allowing the cells to adhere to the surface for $2 \mathrm{~h}$ in a $\mathrm{CO}_{2}$ incubator $\left(5 \% \mathrm{CO}_{2}\right.$ and $90 \%$ humidity), 2 mL of DMEM supplemented with 10\% FBS and 1\% Penicillin/Streptomycin was added. The day of inoculation was considered as day 0 of culturing. Cultures were maintained at $37^{\circ} \mathrm{C}$ in a $\mathrm{CO}_{2}$ incubator. The medium was changed on every second day, after mechanical load. Experiments were performed in three biological replicates $(N=3)$. 
bioRxiv preprint doi: https://doi.org/10.1101/2021.10.26.465847; this version posted October 26, 2021. The copyright holder for this preprint (which was not certified by peer review) is the author/funder, who has granted bioRxiv a license to display the preprint in perpetuity. It is made available under aCC-BY-NC-ND 4.0 International license.

Vágó et al. - Mechanical stimuli entrain the circadian clock during chondrogenesis

\subsection{Uniaxial dynamic mechanical load}

Chondrifying micromass cultures grown in 6-well plates were subjected to uniaxial cyclic compressive force (approx. $0.6 \mathrm{kPa}, 0.05 \mathrm{~Hz}$ ) on every culturing day starting on day 1 for $60 \mathrm{~min}$ at exactly the same time of each day using a custom-made mechanical stimulator unit (for a detailed description of the bioreactor, please see [14]). The equipment applies cyclic load transmitted by the culture medium to micromass cultures. The loading scheme comprises two main components: (a) uniaxial compressive force; and (b) a shear stress component resulting from fluid flow. Samples were collected every 8 hours between 24 - and 72-hours poststimulation after day 6. Control, non-synchronised cultures from the same experiments received a medium change with fresh DMEM containing $10 \%$ FBS at time point 0 , and harvested at the same time points as colonies receiving mechanical load. Harvested micromass cultures were stored at $-80^{\circ} \mathrm{C}$ until RNA isolation.

\subsection{Modulating the function of the molecular clock by longdaysin}

Longdaysin (abbreviated as LDS; Cat. No.: SML0127; Merck) is a molecular clock modifier which blocks casein kinase I (CKI). CKI phosphorylates the PER protein and promotes its degradation [27]. LDS was dissolved in dimethyl sulfoxide (DMSO) at $5 \mathrm{mM}$ and then administered to micromass cultures at the final concentration of $5 \mu \mathrm{M}$ for the duration of the mechanical load on each culturing day. For these experiments, control cultures were treated with equal amount of the vehicle (DMSO).

\subsection{RNA isolation and reverse transcription}

Total RNA was isolated from micromass cultures using the TRI Reagent (Applied Biosystems, Thermo Fisher Scientific, Waltham, MA, USA) according to the instructions of 
bioRxiv preprint doi: https://doi.org/10.1101/2021.10.26.465847; this version posted October 26, 2021. The copyright holder for this preprint (which was not certified by peer review) is the author/funder, who has granted bioRxiv a license to display the preprint in perpetuity. It is made available under aCC-BY-NC-ND 4.0 International license.

Vágó et al. - Mechanical stimuli entrain the circadian clock during chondrogenesis

the manufacturer. After the addition of $20 \%$ chloroform, samples were centrifuged at $4{ }^{\circ} \mathrm{C}$ at $10,000 \times g$ for $15 \mathrm{~min}$. Samples were incubated in $500 \mu \mathrm{L}$ of RNase free isopropanol at $-20^{\circ} \mathrm{C}$ for 1 hour, then total RNA was harvested in RNase-free water and stored at $-80^{\circ} \mathrm{C}$. RNA concentration and purity were determined by a Nanodrop 1000 UV-Vis spectrophotometer (Thermo Fisher Scientific). For gene expression analyses, $1 \mu \mathrm{g}$ of RNA was reverse transcribed into complementary cDNA using the High-Capacity cDNA Reverse Transcription Kit (Thermo Fisher Scientific), as per the protocol supplied by the manufacturer. The assay mixtures for reverse transcriptase reactions contained $1 \mu \mathrm{g}$ RNA, $0.112 \mu \mathrm{M}$ oligo(dT), $0.5 \mathrm{mM}$ dNTP, 200 units of High Capacity RT (Applied Bio-Systems) in $1 \times$ RT buffer. cDNA was stored at $-20^{\circ} \mathrm{C}$.

\subsection{Quantitative real-time polymerase chain reaction (RT-qPCR) analyses}

The expression patterns of clock genes, osteo/chondrogenic transcription factors and genes coding for cartilage ECM structural proteins were determined using RT-qPCR by relative quantification using the $2^{-\Delta \Delta \mathrm{Ct}}$ method. Primer pairs were obtained from Integrated DNA Technologies (Coralville, IA, USA). For sequences of custom-designed primer pairs please see Table S1 in the Supporting Information. SYBR Green-based RT-qPCR reactions were set up using the GoTaq qPCR Master Mix (Promega) and 20 ng input cDNA per each $10-\mu \mathrm{L}$ reaction. Reactions were run in a QuantStudio 3 Real-Time PCR System (Thermo Fisher Scientific) using the following standard thermal profile: activation and initial denaturation at $95^{\circ} \mathrm{C}$ for 2 minutes, followed by 40 cycles of denaturation at $95^{\circ} \mathrm{C}$ for $3 \mathrm{sec}$, annealing and extension at $60^{\circ} \mathrm{C}$ for $30 \mathrm{sec}$, and then final extension at $72^{\circ} \mathrm{C}$ for $20 \mathrm{sec}$. Data was collected during the extension step. Amplification was followed by a melt curve stage consisting of 3 steps: denaturation at $95^{\circ} \mathrm{C}$ for $15 \mathrm{sec}$, annealing at $55^{\circ} \mathrm{C}$ for $1 \mathrm{~min}$, followed by a dissociation step at $0.15^{\circ} \mathrm{C} / \mathrm{sec}$ increments between $55^{\circ} \mathrm{C}$ and $95^{\circ} \mathrm{C}$. Data collection was enabled at each increment of the dissociation step. Amplification data were analysed using the QuantStudio Design and 
bioRxiv preprint doi: https://doi.org/10.1101/2021.10.26.465847; this version posted October 26, 2021. The copyright holder for this preprint (which was not certified by peer review) is the author/funder, who has granted bioRxiv a license to display the preprint in perpetuity. It is made available under aCC-BY-NC-ND 4.0 International license.

Vágó et al. - Mechanical stimuli entrain the circadian clock during chondrogenesis

Analysis Software (version 1.5.1) and exported data were processed using Microsoft Excel (version 2108).

Based on previous literature, three reference genes were analysed for stability during in vitro chondrogenesis at each time point as follows: peptidylprolyl isomerase A (PPIA), 60S ribosomal protein L13 (RPL13) and tyrosine 3-monooxygenase/tryptophan 5-monooxygenase activation protein zeta (YWHAZ). Microsoft Excel was employed to determine the optimal normalising gene between the chosen reference genes based on their expression stability values. Real-time qPCR data for each gene of interest were normalised to the most stable reference gene levels in the same sample.

\subsection{Gene expression data analysis and cosine fits}

Presence of circadian rhythmicity was determined by an extra-sum-of-squares $\mathrm{F}$ test $(\alpha$ $=0.05)$ to test the hypothesis that gene expression was best described by a cosine curve + sloping line, rather than the null hypothesis of a sloping line alone. Curve fitting and $\mathrm{F}$ test was conducted in MATLAB (v 2021a, MathWorks, Natick, MA, USA). A sloping line and single cosine was fitted to all replicate values combined, and returned an intercept and slope for the line, and a period (bounds set to 20-28 hours), amplitude, acrophase and mesor if a significant cosine fit was found. Data is plotted as mean $\pm \mathrm{SD}$, with non-synchronised controls (grey) and cells subjected to mechanical loading (blue), including the linear/cosine fits.

\subsection{Validation of cartilage ECM production in micromass cultures by metachromatic staining}

Micromass cultures were set up onto the surface of $30-\mathrm{mm}$ round glass cover slips (Menzel-Gläser, Menzel GmbH, Braunschweig, Germany) placed into 6-well culture plates. For qualitative and semi-quantitative evaluation of cartilage matrix production, cultures were exposed to the mechanical loading regime on each day from day 1 until day 6 for 1 hour, and 
bioRxiv preprint doi: https://doi.org/10.1101/2021.10.26.465847; this version posted October 26, 2021. The copyright holder for this preprint (which was not certified by peer review) is the author/funder, who has granted bioRxiv a license to display the preprint in perpetuity. It is made available under aCC-BY-NC-ND 4.0 International license.

Vágó et al. - Mechanical stimuli entrain the circadian clock during chondrogenesis

were stained on day 6 after the last 1-hour stimulus with dimethyl-methylene blue (DMMB; $\mathrm{pH}$ 1.8; Merck) metachromatic dyes as previously described [15]. Some colonies received $5 \mu \mathrm{M}$ of LDS for the duration of the mechanical load on each culturing day. The optical density values of DMMB-stained specimens were determined from cultures in 3 independent, biological replicate experiments using a MATLAB image analysis application. Cartilage nodules rich in metachromatic cartilage ECM were defined by an approximate range of values in the RGB colour space and the pixels were counted.

\subsection{Statistical analyses}

All experiments were performed 3 times ( $N=3$ biological replicates). For RT-qPCR reactions, one representative data set is shown out of 3 parallel experiments, each displaying identical trends of changes. Microsoft Excel were employed to analyse all data. For the assessment of cartilage ECM production, optical density values are shown as means \pm standard error of the mean (SEM); statistical differences were determined using paired Student's $t$-test. For RT-qPCR data analysis, expression data of each time point were compared to the previous data point and statistical differences were determined using paired Student's $t$-test. As indicated above, presence of circadian rhythmicity was determined by an extra-sum-of-squares $\mathrm{F}$ test ( $\alpha$ $=0.05)$. 
bioRxiv preprint doi: https://doi.org/10.1101/2021.10.26.465847; this version posted October 26, 2021. The copyright holder for this preprint (which was not certified by peer review) is the author/funder, who has granted bioRxiv a license to display the preprint in perpetuity. It is made available under aCC-BY-NC-ND 4.0 International license.

Vágó et al. - Mechanical stimuli entrain the circadian clock during chondrogenesis

\section{Results}

\subsection{Intermittent cyclic mechanical load augmented metachromatic cartilage matrix production} in micromass cultures in a circadian clock-dependent manner

We first checked whether uniaxial cyclic compressive force administered to micromass cultures every day between days 1 and 6 for $60 \mathrm{~min}$ at the same time of each day influenced metachromatic cartilage ECM production by day 6. Following DMMB staining, image analysis confirmed that mechanical stimulation (MS) massively enhanced matrix production by $233 \%$ ( $\pm 3.96 \% ; P<0.001)$ compared to the control (Fig. $2 A)$. Some other cultures were exposed to $5 \mu \mathrm{M}$ of LDS for $1 \mathrm{~h}$ every day; perturbing the circadian clock by this treatment did not interfere with cartilage ECM production by day $6(91.19 \pm 11.4 \% ; P=0.26)$. Combined exposure to MS and LDS for $60 \mathrm{~min}$ for 6 days resulted in a significant $(155 \pm 1.89 \%)$ increase in metachromatic matrix production $(P<0.001 v s$. the control), but it reduced ECM deposition compared to MS alone $(P<0.001)$.

To assess whether the observed changes in cartilage ECM production were detectable at the molecular level, the gene expression patterns of key chondrogenic marker genes, including the master transcription factor $S O X 9$, the alpha-1 chain of collagen type II (COL2A1), and aggrecan $(A C A N)$ were tested using RT-qPCR (Fig. 2B). COL2A1 mRNA expression was significantly upregulated $(1.4$-fold $\pm 0.093 ; P=0.009)$ in cultures exposed to rhythmic MS for 6 consecutive days, relative to the control. ACAN levels remained unchanged, whereas SOX9 expression was downregulated following MS in 6-day-old colonies compared to the control. When the circadian clock modulator compound LDS was applied for $1 \mathrm{~h}$ on every culturing day for 6 days, all three markers displayed a significant downregulation. Combined treatment with LDS and cyclic mechanical load resulted in lower gene expression levels for the studied chondrogenic marker genes relative to the untreated control (Fig. 2B). 
bioRxiv preprint doi: $\mathrm{https}$ //doi.org/10.1101/2021.10.26.465847; this version posted October 26, 2021. The copyright holder for this preprint (which was not certified by peer review) is the author/funder, who has granted bioRxiv a license to display the preprint in perpetuity. It is made available under aCC-BY-NC-ND 4.0 International license.

Vágó et al. - Mechanical stimuli entrain the circadian clock during chondrogenesis

A.

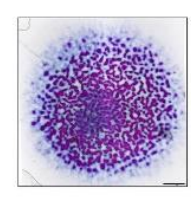

CTRL

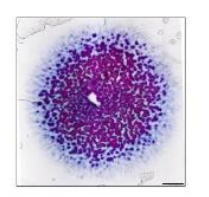

MS

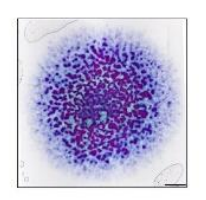

LDS

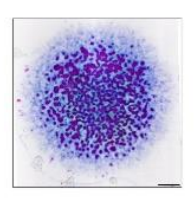

MS+LDS

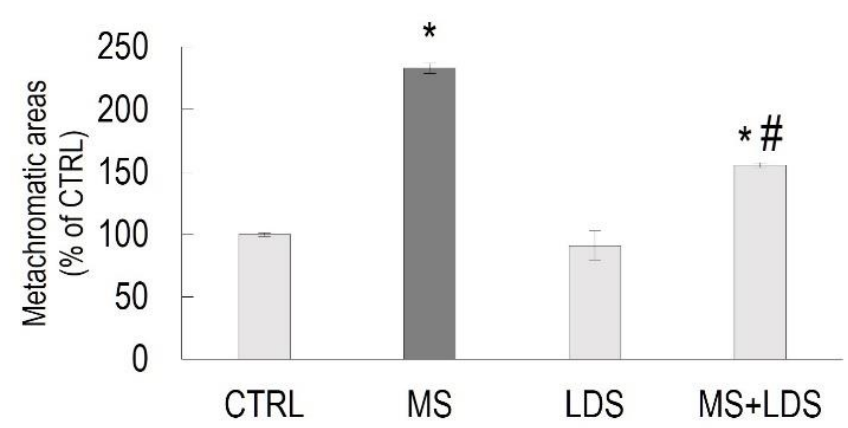

B.

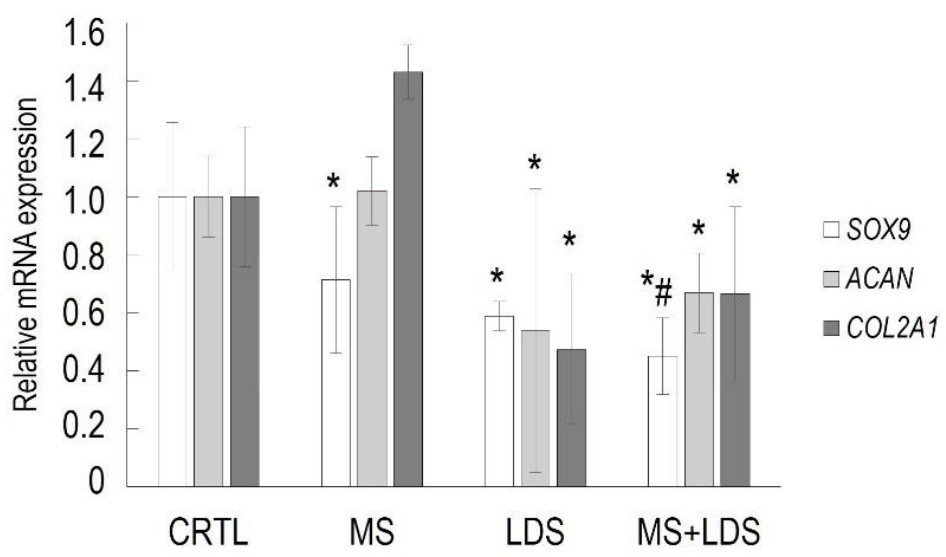

Figure 2. Mechanical load administered to micromass cultures for 60 min on days 1 through 6 increased chondrogenesis and metachromatic cartilage ECM production by day 6 in a circadian clock-dependent mechanism. A. Metachromatic cartilage ECM accumulation during chondrogenesis in control vs. mechanical load-induced cultures, with or without longdaysin (LDS) treatment, as determined by DMMB (qualitative) staining assay. Original magnification was $2 \times$. Scale bar, $1 \mathrm{~mm}$. The bar chart shows the results of a MATLAB-based image analysis of metachromatic areas in mechanically loaded vs. control cultures, with or without LDS treatment. Data are expressed as mean \pm SEM. Statistical significance $(P<0.05)$ between mechanically stimulated and control cultures is indicated by asterisks $\left({ }^{*}\right)$, and between LDS-treated and untreated samples by a hash sign (\#). Representative data out of 3 independent experiments. B. Cartilage-specific marker gene expression on day 6 following mechanical loading regime, with or without treatment with the circadian clock regulator LDS. Data are expressed as the mean $\pm S D$ relative to the control and normalised against the reference gene RPL13. Statistical significance $(P<0.05)$ between gene expression levels is indicated by asterisks (relative to vehicle control) or a hash sign (between LDS-treated and untreated cultures). CTRL, control; MS, mechanical stimuli; LDS, longdaysin 
bioRxiv preprint doi: https://doi.org/10.1101/2021.10.26.465847; this version posted October 26, 2021. The copyright holder for this preprint (which was not certified by peer review) is the author/funder, who has granted bioRxiv a license to display the preprint in perpetuity. It is made available under aCC-BY-NC-ND 4.0 International license.

Vágó et al. - Mechanical stimuli entrain the circadian clock during chondrogenesis

Taken together, these results suggest that rhythmic mechanical stimuli may have enhanced chondrogenesis and ECM deposition, at least partially, via a circadian clockdependent mechanism.

\subsection{The molecular clock genes exhibited a synchronised oscillatory pattern during early}

chondrogenesis following mechanical load

Transcripts for the clock genes BMAL1, PER2/3, CRY1/CRY2 and REV-ERB known to control the molecular clockwork were previously detected in chondrifying cells of micromass cultures, indicating that these genes were already expressed and functional during early chondrogenesis [15]. To establish whether the clock genes exhibited a rhythmic expression over time following MS, 1-day-old micromass cultures were exposed to cyclic intermittent uniaxial cyclic mechanical load for 1 hour every culturing day for 6 days at the same time of each day. Samples for total RNA isolation were collected at $24 \mathrm{~h}$ after the last loading regimen (time point 0 ) and then at every 8 hours for the period of $24-72 \mathrm{~h}$ (over the course of $48 \mathrm{~h}$ ) to identify oscillatory peaks in clock gene expression. The relative quantity (RQ) and relative SD (RSD) values for the core clock genes after being normalised to $R P L 13$, the most stable reference gene tested, at each time point, are shown in Table $S 2$ in the Supporting Information. As indicated, the normalised relative quantity values for each gene of interest at the $24 \mathrm{~h}$ time point was set to 1.0 .

We detected a synchronised oscillatory expression pattern for the majority of the clock genes studied (BMAL1, PER2, PER3, CRY1, and CRY2) over the investigated $72 \mathrm{~h}$ period; the rhythmic patterns for the genes could be fitted with a non-linear cosinor regression in case of BMAL1, CRY1, and PER3 (Fig. 3). There was an approx. 6-hour phase angle between the positive phase and negative phase of the clock (i.e. BMAL1 vs. CRY1 and PER3), and the period was approximately 20-24 hours. The parameters of the observed circadian expression patterns 
bioRxiv preprint doi: https://doi.org/10.1101/2021.10.26.465847; this version posted October 26, 2021. The copyright holder for this preprint (which was not certified by peer review) is the author/funder, who has granted bioRxiv a license to display the preprint in perpetuity. It is made available under aCC-BY-NC-ND 4.0 International license.

Vágó et al. - Mechanical stimuli entrain the circadian clock during chondrogenesis

for 6-day-old chondrogenic cultures synchronised with rhythmic mechanical load are shown in

\section{Table 2.}
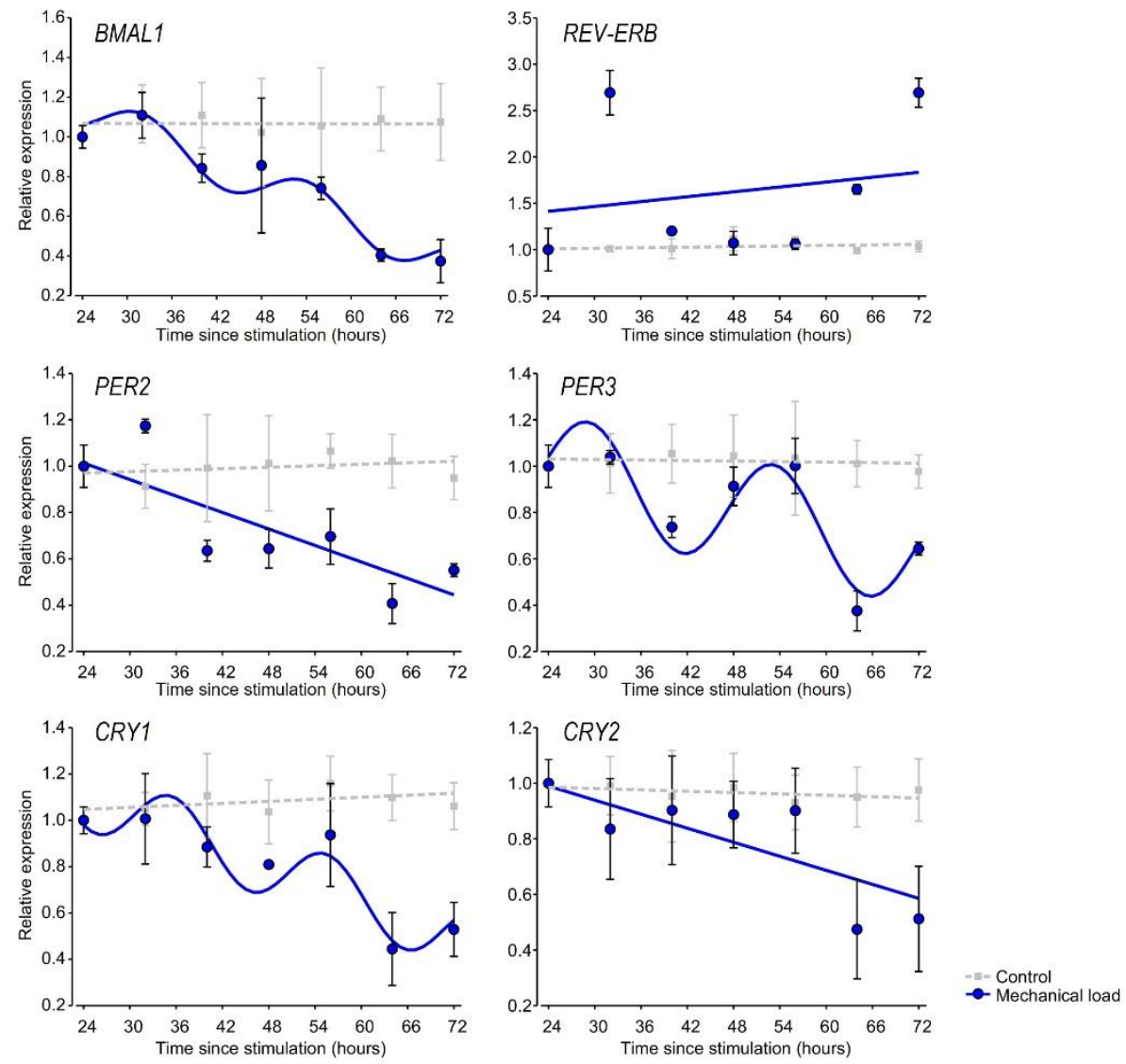

Figure 3. Circadian rhythm dynamics in clock gene expression in 6-day-old differentiating embryonic limb budderived chondroprogenitor cells of micromass cultures following synchronisation with uniaxial cyclic mechanical load. Quantitative RT-PCR analyses followed by cosine fits showing temporal expression profiles of the clock genes collected every 8 hours between $24 \mathrm{~h}-72 \mathrm{~h}$ post-synchronisation with mechanical load (solid blue line) versus non-stimulated control cultures (broken grey line) collected at the same time points. Data are expressed as the mean of transcript levels $\pm S D$ relative to the $24 \mathrm{~h}$ time point and normalised against the reference gene $R P L 13$. Representative data are shown out of 3 independent experiments, each exhibiting similar patterns of gene expression profiles.

\subsection{The chondrogenic marker genes also show a circadian expression pattern during}

\section{chondrogenesis}

Chondrogenic differentiation in embryonic limb bud-derived micromass is controlled by the osteo-chondrogenic transcription factors SOX6, SOX9, and RUNX2. These transcription factors are upstream regulators of genes encoding cartilage ECM components such as $A C A N$ and COL2A1. In order to establish whether the expression of these marker genes also showed 
bioRxiv preprint doi: https://doi.org/10.1101/2021.10.26.465847; this version posted October 26, 2021. The copyright holder for this preprint (which was not certified by peer review) is the author/funder, who has granted bioRxiv a license to display the preprint in perpetuity. It is made available under aCC-BY-NC-ND 4.0 International license.

Vágó et al. - Mechanical stimuli entrain the circadian clock during chondrogenesis

an oscillatory pattern, their transcript levels were analysed by RT-qPCR, and then the expression values were fitted with the cosine function to reveal circadian patterns (Fig. 4). The cosinor parameters of the observed circadian expression patterns for the marker genes in chondrogenic cultures are summarised in Table 2.
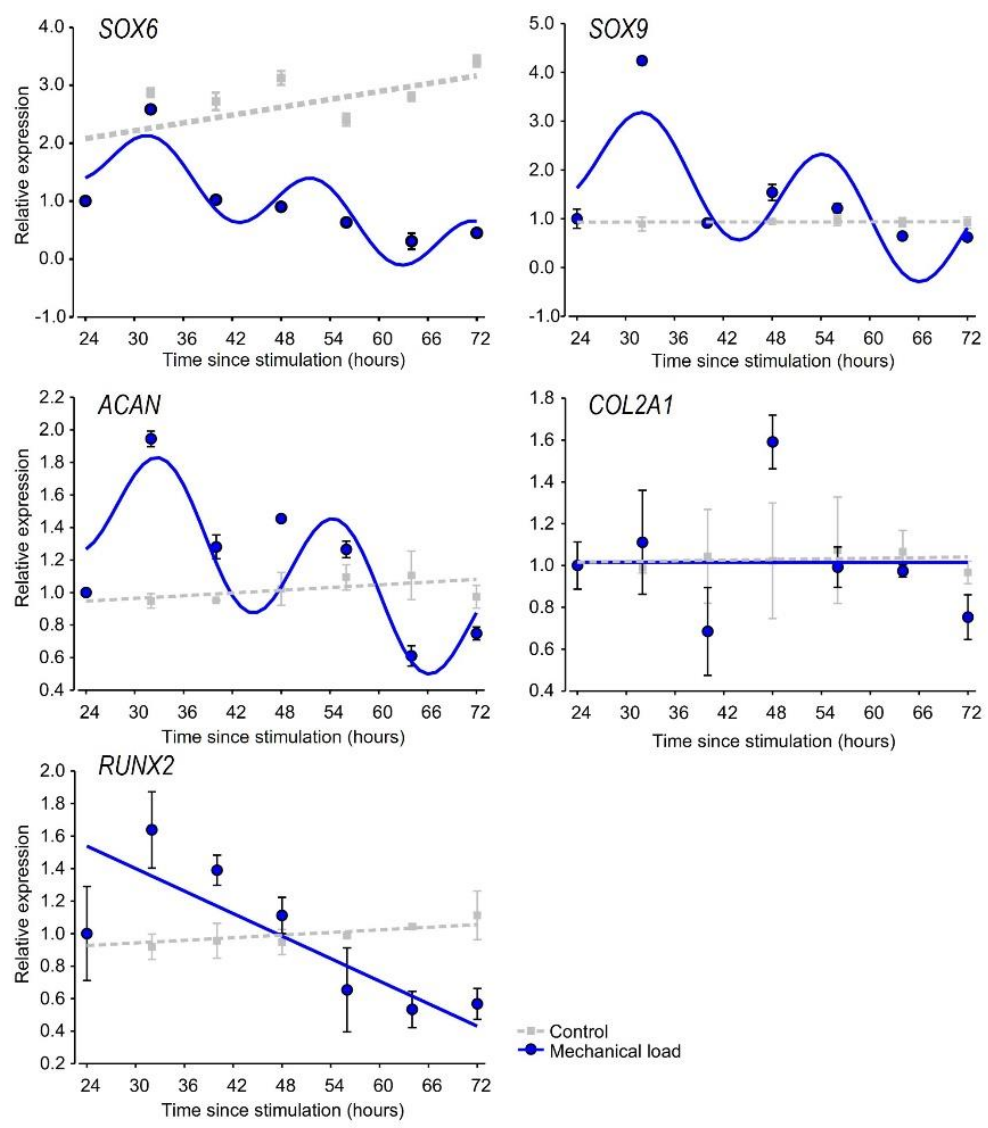

Figure 4. Circadian rhythm dynamics in clock gene expression in 6-day-old differentiating embryonic limb budderived chondroprogenitor cells of micromass cultures following synchronisation with uniaxial cyclic mechanical load. Quantitative RT-PCR analyses followed by cosine fits showing temporal expression profiles of chondrogenic marker genes collected every 8 hours between $24 \mathrm{~h}-72 \mathrm{~h}$ post-synchronisation with mechanical load (solid blue

line) versus non-stimulated control cultures (broken grey line) collected at the same time points. Data are expressed as the mean of transcript levels \pm SD relative to the $24 \mathrm{~h}$ time point and normalised against the reference gene RPL13. Representative data are shown out of 3 independent experiments, each exhibiting similar patterns of gene expression profiles.

In 6-day-old chondrogenic micromass cultures synchronised by cyclic uniaxial mechanical load, SOX6, SOX9, and ACAN displayed oscillatory expression patterns (Fig. 4). In contrast, no sinusoidal circadian pattern could be detected for RUNX2 and COL2A1. The relative quantity (RQ) and relative $\mathrm{SD}(\mathrm{RSD})$ values for the core clock genes after being 
bioRxiv preprint doi: $h$ ttps://doi.org/10.1101/2021.10.26.465847; this version posted October 26, 2021. The copyright holder for this preprint (which was not certified by peer review) is the author/funder, who has granted bioRxiv a license to display the preprint in perpetuity. It is made available under aCC-BY-NC-ND 4.0 International license.

Vágó et al. - Mechanical stimuli entrain the circadian clock during chondrogenesis

normalised to $R P L 13$, the most stable reference gene tested, at each time point, are shown in Table $S 2$ in the Supporting Information. These findings suggest a circadian regulation of chondrogenic marker genes in micromass cultures during chondrogenesis as a result of intermittent mechanical load, and that the two key transcription factors $S O X 9$ and $R U N X 2$ may be differentially regulated by the molecular clock following entrainment with MS.

\section{A. Mechanical load}

$\begin{array}{lrrrrrr}\text { Gene symbol } & \mathrm{F} & P & \text { Amplitude } & \text { Acrophase }(\mathrm{h}) & \text { Period }(\mathrm{h}) & \mathrm{R}^{2} \\ \text { BMAL1 } & 10.665 & <0.001 & \mathbf{0 . 1 0 6} & 10.154 & 22.041 & 0.957 \\ \text { CRY1 } & 12.814 & <0.001 & \mathbf{0 . 1 4 2} & 15.549 & 20.000 & 0.920 \\ \text { CRY2 } & 2.854 & 0.070 & 0.098 & 23.377 & 28.000 & 0.781 \\ \text { PER2 } & 0.349 & 0.791 & 0.052 & 24.000 & 27.572 & 0.690 \\ \text { PER3 } & 27.062 & <0.001 & -0.237 & 17.233 & 24.048 & 0.910 \\ \text { REV-ERB } & 0.810 & 0.507 & 0.358 & 8.608 & 28.000 & 0.204 \\ \text { SOX9 } & 6.566 & 0.005 & 1.086 & 10.209 & 22.166 & 0.671 \\ \text { COL2A1 } & 1.719 & 0.203 & -0.200 & 10.036 & 28.000 & 0.270 \\ \text { ACAN } & 10.423 & 0.001 & 0.379 & 11.640 & 21.603 & 0.790 \\ \text { SOX6 } & 8.725 & 0.001 & 0.555 & 12.203 & 20.000 & 0.800 \\ \text { RUNX2 } & 2.649 & 0.084 & 0.227 & 11.141 & 28.000 & 0.724\end{array}$

\section{B. Non-stimulated (control)}

$\begin{array}{lrrrrrr}\text { Gene symbol } & \mathrm{F} & P & \text { Amplitude } & \text { Acrophase }(\mathrm{h}) & \text { Period }(\mathrm{h}) & \mathrm{R}^{2} \\ \text { BMAL1 } & 3.290 & 0.242 & 0.053 & 8.595 & 28.000 & 0.839 \\ \text { CRY1 } & 7.468 & 0.120 & 0.064 & 15.972 & 21.245 & 0.938 \\ \text { CRY2 } & 1.042 & 0.524 & 0.021 & 24.000 & 23.424 & 0.726 \\ \text { PER2 } & 0.429 & 0.755 & 0.040 & 20.847 & 20.000 & 0.420 \\ \text { PER3 } & 0.284 & 0.837 & 0.019 & 16.375 & 21.851 & 0.346 \\ \text { REV-ERB } & 0.596 & 0.676 & -0.041 & 8.461 & 28.000 & 0.497 \\ \text { SOX9 } & 0.999 & 0.535 & 0.039 & 24.000 & 28.000 & 0.620 \\ \text { COL2A1 } & 1.076 & 0.515 & 0.043 & 17.523 & 21.490 & 0.627 \\ \text { ACAN } & 0.563 & 0.690 & 0.057 & 0.180 & 28.000 & 0.569 \\ \text { SOX6 } & 0.196 & 0.892 & 0.402 & 11.812 & 28.000 & 0.574 \\ \text { RUNX2 } & 0.326 & 0.812 & -0.033 & 11.234 & 23.340 & 0.684\end{array}$

Table 2. Cosinor analysis parameters of core clock and chondrogenic marker gene expression in chondrogenic cultures following mechanical load $(\mathbf{A})$ and in non-stimulated control cultures $(\mathbf{B})$. $F$, extra sums of squares $F$ test value; $P$, probability value; $\mathrm{R}^{2}$, coefficient of determination 
bioRxiv preprint doi: https://doi.org/10.1101/2021.10.26.465847; this version posted October 26, 2021. The copyright holder for this preprint (which was not certified by peer review) is the author/funder, who has granted bioRxiv a license to display the preprint in perpetuity. It is made available under aCC-BY-NC-ND 4.0 International license.

Vágó et al. - Mechanical stimuli entrain the circadian clock during chondrogenesis

\section{Discussion}

This is the first report to show that cyclic uniaxial mechanical stimulation augments chondrogenic differentiation in limb bud-derived micromass cultures by entraining the circadian molecular clock. When biochemical perturbation of the clock is combined with mechanical stimulation, a reduction was detected in the mechanical stimulation-driven enhanced chronodrogenesis. These observations show that a functional circadian clock is beneficial to chondrogenesis, and that in the absence of peripheral Zeitgebers during early development, mechanical stimulation can synchronise these molecular clocks.

The circadian activity of peripheral clocks, which are expressed in almost all nucleated cells of multicellular organisms, is co-ordinated by the central pacemaker clock in the central nervous system. These peripheral clocks in turn control rhythms in local molecular and cellular processes. Transcriptional analyses have shown that a large proportion of the genome is clockcontrolled; more than $50 \%$ of protein-encoding genes display circadian oscillatory patterns [28]. In addition to transcriptional changes, circadian regulation of cell physiology arises from the rhythmic control of post-transcriptional processes, including RNA splicing, protein translation, and post-translational modifications. Indeed, a recent study confirmed that 145 of the 1177 identified proteins (12\%) displayed 24-hour rhythmic changes in the proteome of femoral head cartilage [29].

Although the master clock is entrained by light, and peripheral clocks are normally entrained by the central pacemaker, there are other cell and tissue-specific factors (Zeitgebers) that can synchronise these peripheral clocks. Exposing cultured cells, including chondrogenic progenitor cells, to a pulse of serum in vitro synchronizes robust 24-hour transcription cycles $[15,28]$. Light exposure at the incorrect time of day shifts the phase of pacemaker neuronal clocks and peripheral tissue clocks, and can impair cognitive performance [30]. Feeding can independently synchronize peripheral tissue clocks in the liver and kidneys; food consumed at 
bioRxiv preprint doi: https://doi.org/10.1101/2021.10.26.465847; this version posted October 26, 2021. The copyright holder for this preprint (which was not certified by peer review) is the author/funder, who has granted bioRxiv a license to display the preprint in perpetuity. It is made available under aCC-BY-NC-ND 4.0 International license.

\section{Vágó et al. - Mechanical stimuli entrain the circadian clock during chondrogenesis}

the wrong time of day may therefore lead to misalignment in clock timing [31]. Irregular sleep and eating schedules can misalign clocks in metabolic organs, leading to obesity and diabetes [28]. Understanding the molecular actions of the circadian clock, and the cell and tissue-specific Zeitgebers may provide insight into the mechanism of cell and tissue homeostasis in developing and mature tissues.

Given its location and poor circulation due to its avascular nature, the molecular clock in chondrocytes of articular cartilage is unlikely to be directly entrained by light and metabolic cues. In this work, we have shown, for the first time, that properly adjusted mechanical stimuli that chondrogenic cells are also exposed to in vivo are able to entrain the molecular clockwork during chondrogenic differentiation. The impact of mechanical signalling on developing and mature cartilage is well appreciated, albeit the specific mechanotransduction pathways are not completely understood. We have previously shown that mechanical stimuli augment in vitro cartilage formation via promoting both differentiation and matrix production of chondrogenic cells, through the opposing regulation of the PKA/CREB-Sox9 and the PP2A signalling pathways in the embryonic limb bud-derived micromass model [14]. Mechanosensitive ion channels such as transient receptor potential vanilloid 4 (TRPV4), Piezo1, and Piezo2 play important functional roles in chondrocyte mechanosensation [32]. Mechanical cues are also pivotal in modulating the chondrogenic differentiation of MSCs. Dynamic compressive loading has been previously shown to stimulate MSC chondrogenesis, with reports describing upregulated Sox 9 expression, and increased glycosaminoglycan and collagen type II production $[6]$.

Since certain components (e.g. $C L O C K$ ) of the molecular clockwork were shown to be mechanosensitive [19], we attempted to synchronise the clock in differentiating chondrocytes using a cyclic mechanical loading regimen. Rhythmic mechanical stimulation was shown to have the ability to entrain human MSCs, which represents a novel clock synchronisation 
bioRxiv preprint doi: https://doi.org/10.1101/2021.10.26.465847; this version posted October 26, 2021. The copyright holder for this preprint (which was not certified by peer review) is the author/funder, who has granted bioRxiv a license to display the preprint in perpetuity. It is made available under aCC-BY-NC-ND 4.0 International license.

Vágó et al. - Mechanical stimuli entrain the circadian clock during chondrogenesis

approach independent of chemical or temperature cues [22]. Indeed, uniaxial cyclic compressive force (approx. $0.6 \mathrm{kPa}, 0.05 \mathrm{~Hz}$ ) administered to cells of chondrifying micromass cultures on every culturing day for 6 days (for 60 min each day) synchronised the expression of the core clock genes and cartilage marker genes, and resulted in augmented cartilage ECM deposition. We also observed that differentiating chondrocytes responded differently to circadian synchronising signals; in serum shock-synchronised cells, BMAL1, CRY1, and PER2 displayed sinusoidal expression patterns [15], whereas mechanical stimuli caused BMAL1, CRY1, and PER3 to follow a sinusoidal pattern. Additionally, whilst COL2A1 showed a sinusoidal expression pattern in serum-shocked cultures [15], it did not become rhythmic following entrainment by MS.

Therefore, it appears that chondrogenic cells cultured in a mechanical environment exhibit a different profile of the molecular circadian clock compared to synchronisation by glucocorticoids and growth factors present in high levels of foetal serum. With regards to the negative loop of the core clock, $C R Y 2$ also displayed a robust sinusoidal pattern but its $P$ value (0.07) was just shy of the chosen cut-off significance threshold (0.05; see Table 2$)$. However, PER2 did not show oscillatory expression following MS; this is in contrast to the pattern identified in human bone marrow-derived MSCs (BMSC) and dental pulp stem cells (DPSC), where PER2 was found to be responding to rhythmic mechanical stretch [22]. While the rhythmic expression of $R E V-E R B$ could also not be elicited by MS in our model, it displayed a sinusoid pattern in bone marrow-derived MSC and dental pulp stem cells exposed to mechanical stress [22].

We observed that the mechanical loading regime significantly increased cartilage ECM production and upregulated COL2Al expression. At the same time, SOX9 expression was downregulated, probably indicating that the dynamic mechanical microenvironment accelerated the pace of chondrogenic differentiation; the observed lower transcript levels of 
bioRxiv preprint doi: https://doi.org/10.1101/2021.10.26.465847; this version posted October 26, 2021. The copyright holder for this preprint (which was not certified by peer review) is the author/funder, who has granted bioRxiv a license to display the preprint in perpetuity. It is made available under aCC-BY-NC-ND 4.0 International license.

Vágó et al. - Mechanical stimuli entrain the circadian clock during chondrogenesis

SOX9 are characteristic to more mature chondrocytes [33]. When the circadian clock modulator LDS was applied in addition to mechanical load, a moderately enhanced metachromatic ECM production was observed, despite reduced chondrogenic marker gene expression. This could have been caused by cross-talk with other, circadian clock-independent signalling pathways (i.e. PKA/CREB-Sox9 and PP2A; [14]) through the regulation of glycosaminoglycan deposition at the post-transcriptional level.

The observed differences between our model and the MSC-based models described above can be attributed to (1) the different stage of differentiation of the cells (undifferentiated/uncommitted cells versus chondrogenic cells/chondrocytes); (2) the different nature of synchronisation applied (chemical/metabolic versus mechanical signals); (3) and the specific nature of the mechanical environment (stretch versus compression; cyclic versus static), which probably activate different downstream pathways that eventually result in clock entrainment. Nevertheless, the fact that properly set MS entrained the core clock of differentiating chondrocytes, and that it enhanced cartilage ECM production at least partially via synchronised cartilage marker gene expression patterns compared to unstimulated cells is of key importance. 
bioRxiv preprint doi: https://doi.org/10.1101/2021.10.26.465847; this version posted October 26, 2021. The copyright holder for this preprint (which was not certified by peer review) is the author/funder, who has granted bioRxiv a license to display the preprint in perpetuity. It is made available under aCC-BY-NC-ND 4.0 International license.

Vágó et al. - Mechanical stimuli entrain the circadian clock during chondrogenesis

\section{Conclusions and Perspectives}

The circadian clock has been shown to play a key regulatory role in various tissues and organs, including the musculoskeletal system, and more specifically cartilage $[15,34]$. Our results, for the first time, suggest that entraining chondroprogenitor clocks during chondrogenesis by uniaxial cyclic mechanical load method offers an insightful way in which these cells can be primed to produce more abundant cartilage ECM. Mechanical entrainment represents a non-invasive means by which the quality and quantity of tissue-engineered cartilage could be augmented through the control of the circadian clock in the critical period of chondrogenesis, avoiding the need for additional exogenous chemical or thermal stimuli. A deeper understanding of the biomechanical forces within the developing joint and their downstream signalling pathways in vivo may enhance our knowledge of postnatal articular cartilage development. Recapitulating the mechanical environment associated with cartilage formation and homeostasis during chondrogenic differentiation in vitro may promote the development of a cellular phenotype resembling chondrocytes in native articular cartilage, and advance the field of cartilage replacement strategies. It is therefore vital that a combined approach of a biomechanical environment and chondrochronology be considered when optimising future cartilage tissue engineering applications.

\section{Acknowledgements}

The authors are thankful to Mrs. Krisztina Biróné Barna and Ms. Do Hwi Lee for technical assistance. We wish to thank Dr. Peter Nagy at the Department of Biophysics and Cell Biology, University of Debrecen, for developing the MATLAB-based image analysis software. 
bioRxiv preprint doi: https://doi.org/10.1101/2021.10.26.465847; this version posted October 26, 2021. The copyright holder for this preprint (which was not certified by peer review) is the author/funder, who has granted bioRxiv a license to display the preprint in perpetuity. It is made available under aCC-BY-NC-ND 4.0 International license.

Vágó et al. - Mechanical stimuli entrain the circadian clock during chondrogenesis

\section{Author Contributions}

Conception and design: Csaba Matta, Róza Zákány; Analysis and interpretation of the data: Judit Vágó, Éva Katona, Roland Takács, Daan van der Veen, Csaba Matta; Drafting of the article: Csaba Matta; Critical revision of the article for important intellectual content: all authors; Final approval of the article: all authors; Statistical expertise: Daan van der Veen; Obtaining of funding: Csaba Matta, Róza Zákány; Administrative, technical, or logistic support: Csaba Matta; Collection and assembly of data: Judit Vágó, Éva Katona, Roland Takács.

\section{Funding}

CM was supported by the Premium Postdoctoral Research Fellowship of the Eötvös Loránd Research Network (ELKH), and the Young Researcher Excellence Programme (grant number: FK-134304) of the National Research, Development and Innovation Office, Hungary. CM was also supported by the EFOP-3.6.3-VEKOP-16-2017-00009 project co-financed by the EU and the European Social Fund. Project no. TKP2020-NKA-04 was implemented with the support provided by the National Research, Development and Innovation Fund of Hungary, financed under the 2020-4.1.1-TKP2020 funding scheme. The funding bodies were not involved in the study design, data collection, analysis, and interpretation. The decision to submit the paper for publication was not influenced by any funding bodies.

\section{Competing interest statement}

The authors declare no conflicts of interest. This paper was written by the authors within the scope of their academic and research positions. None of the authors have any relationships with other people or organisations that could be construed as biased or inappropriate. 
bioRxiv preprint doi: https://doi.org/10.1101/2021.10.26.465847; this version posted October 26, 2021. The copyright holder for this preprint (which was not certified by peer review) is the author/funder, who has granted bioRxiv a license to display the preprint in perpetuity. It is made available under aCC-BY-NC-ND 4.0 International license.

Vágó et al. - Mechanical stimuli entrain the circadian clock during chondrogenesis

\section{References}

[1] B.J. Bielajew, J.C. Hu, K.A. Athanasiou, Collagen: quantification, biomechanics, and role of minor subtypes in cartilage, Nat Rev Mater 5(10) (2020) 730-747.

[2] Y. Luo, D. Sinkeviciute, Y. He, M. Karsdal, Y. Henrotin, A. Mobasheri, P. Onnerfjord, A. Bay-Jensen, The minor collagens in articular cartilage, Protein Cell 8(8) (2017) 560-572.

[3] S.M. Richardson, G. Kalamegam, P.N. Pushparaj, C. Matta, A. Memic, A. Khademhosseini, R. Mobasheri, F.L. Poletti, J.A. Hoyland, A. Mobasheri, Mesenchymal stem cells in regenerative medicine: Focus on articular cartilage and intervertebral disc regeneration, Methods 99 (2016) 69-80. [4] H. Jahr, C. Matta, A. Mobasheri, Physicochemical and biomechanical stimuli in cell-based articular cartilage repair, Curr Rheumatol Rep 17(3) (2015) 22.

[5] J. Sanchez-Adams, H.A. Leddy, A.L. McNulty, C.J. O'Conor, F. Guilak, The mechanobiology of articular cartilage: bearing the burden of osteoarthritis, Curr Rheumatol Rep 16(10) (2014) 451.

[6] N. Fahy, M. Alini, M.J. Stoddart, Mechanical stimulation of mesenchymal stem cells: Implications for cartilage tissue engineering, J Orthop Res 36(1) (2018) 52-63.

[7] K.W. Ng, R.L. Mauck, C.C. Wang, T.A. Kelly, M.M. Ho, F.H. Chen, G.A. Ateshian, C.T. Hung, Duty Cycle of Deformational Loading Influences the Growth of Engineered Articular Cartilage, Cell Mol Bioeng 2(3) (2009) 386-394.

[8] E.M. Roos, L. Dahlberg, Positive effects of moderate exercise on glycosaminoglycan content in knee cartilage: a four-month, randomized, controlled trial in patients at risk of osteoarthritis, Arthritis Rheum 52(11) (2005) 3507-14.

[9] A.C. Osborne, K.J. Lamb, J.C. Lewthwaite, G.P. Dowthwaite, A.A. Pitsillides, Short-term rigid and flaccid paralyses diminish growth of embryonic chick limbs and abrogate joint cavity formation but differentially preserve pre-cavitated joints, J Musculoskelet Neuronal Interact 2(5) (2002) 448-56.

[10] M.R. Simon, The effect of dynamic loading on the growth of epiphyseal cartilage in the rat, Acta Anat (Basel) 102(2) (1978) 176-83.

[11] G.S. Beaupre, S.S. Stevens, D.R. Carter, Mechanobiology in the development, maintenance, and degeneration of articular cartilage, J Rehabil Res Dev 37(2) (2000) 145-51.

[12] S.H. Elder, J.H. Kimura, L.J. Soslowsky, M. Lavagnino, S.A. Goldstein, Effect of compressive loading on chondrocyte differentiation in agarose cultures of chick limb-bud cells, J Orthop Res 18(1) (2000) 78-86.

[13] I. Takahashi, G.H. Nuckolls, K. Takahashi, O. Tanaka, I. Semba, R. Dashner, L. Shum, H.C. Slavkin, Compressive force promotes sox 9 , type II collagen and aggrecan and inhibits IL-1beta expression resulting in chondrogenesis in mouse embryonic limb bud mesenchymal cells, J Cell Sci 111 ( Pt 14) (1998) 2067-76.

[14] T. Juhasz, C. Matta, C. Somogyi, E. Katona, R. Takacs, R.F. Soha, I.A. Szabo, C. Cserhati, R. Szody, Z. Karacsonyi, E. Bako, P. Gergely, R. Zakany, Mechanical loading stimulates chondrogenesis via the PKA/CREB-Sox9 and PP2A pathways in chicken micromass cultures, Cell Signal 26(3) (2014) 468-82.

[15] M.A. Alagha, J. Vago, E. Katona, R. Takacs, D. van der Veen, R. Zakany, C. Matta, A Synchronized Circadian Clock Enhances Early Chondrogenesis, Cartilage (2020) 1947603520903425.

[16] N. Yang, J. Williams, V. Pekovic-Vaughan, P. Wang, S. Olabi, J. McConnell, N. Gossan, A. Hughes, J. Cheung, C.H. Streuli, Q.J. Meng, Cellular mechano-environment regulates the mammary circadian clock, Nat Commun 8 (2017) 14287.

[17] N. Gossan, R. Boot-Handford, Q.J. Meng, Ageing and osteoarthritis: a circadian rhythm connection, Biogerontology 16(2) (2015) 209-19.

[18] A. Simoni, W. Wolfgang, M.P. Topping, R.G. Kavlie, R. Stanewsky, J.T. Albert, A mechanosensory pathway to the Drosophila circadian clock, Science 343(6170) (2014) 525-8.

[19] K. Kanbe, K. Inoue, C. Xiang, Q. Chen, Identification of clock as a mechanosensitive gene by largescale DNA microarray analysis: downregulation in osteoarthritic cartilage, Mod Rheumatol 16(3) (2006) 131-6. 
bioRxiv preprint doi: https://doi.org/10.1101/2021.10.26.465847; this version posted October 26, 2021. The copyright holder for this preprint (which was not certified by peer review) is the author/funder, who has granted bioRxiv a license to display the preprint in perpetuity. It is made available under aCC-BY-NC-ND 4.0 International license.

Vágó et al. - Mechanical stimuli entrain the circadian clock during chondrogenesis

[20] M. Wang, D. Yu, L. Zheng, B. Hong, H. Li, X. Hu, K. Zhang, Y. Mou, Mechanical Stress Affects Circadian Rhythm in Skeletal Muscle (C2C12 Myoblasts) by Reducing Per/Cry Gene Expression and Increasing Bmal1 Gene Expression, Med Sci Monit 27 (2021) e928359.

[21] N. Gossan, L. Zeef, J. Hensman, A. Hughes, J.F. Bateman, L. Rowley, C.B. Little, H.D. Piggins, M. Rattray, R.P. Boot-Handford, Q.J. Meng, The circadian clock in murine chondrocytes regulates genes controlling key aspects of cartilage homeostasis, Arthritis Rheum 65(9) (2013) 2334-45.

[22] E.H. Rogers, S.A. Fawcett, V. Pekovic-Vaughan, J.A. Hunt, Comparing Circadian Dynamics in Primary Derived Stem Cells from Different Sources of Human Adult Tissue, Stem Cells Int 2017 (2017) 2057168.

[23] T. Takarada, A. Kodama, S. Hotta, M. Mieda, S. Shimba, E. Hinoi, Y. Yoneda, Clock genes influence gene expression in growth plate and endochondral ossification in mice, J Biol Chem 287(43) (2012) 36081-95.

[24] S. Yu, Q. Tang, M. Xie, X. Zhou, Y. Long, Y. Xie, F. Guo, L. Chen, Circadian BMAL1 regulates mandibular condyle development by hedgehog pathway, Cell Prolif 53(1) (2020) e12727. [25] N.Q. Le, N.T. Binh, T. Takarada, M. Takarada-lemata, E. Hinoi, Y. Yoneda, Negative correlation between Per 1 and Sox 6 expression during chondrogenic differentiation in pre-chondrocytic ATDC5 cells, J Pharmacol Sci 122(4) (2013) 318-25.

[26] R.C. Poulsen, J.I. Hearn, N. Dalbeth, The circadian clock: a central mediator of cartilage maintenance and osteoarthritis development?, Rheumatology (Oxford) 60(7) (2021) 3048-3057. [27] D. Kolarski, A. Sugiyama, G. Breton, C. Rakers, D. Ono, A. Schulte, F. Tama, K. Itami, W. Szymanski, T. Hirota, B.L. Feringa, Controlling the Circadian Clock with High Temporal Resolution through Photodosing, J Am Chem Soc 141(40) (2019) 15784-15791.

[28] R. Allada, J. Bass, Circadian Mechanisms in Medicine, N Engl J Med 384(6) (2021) 550-561. [29] M. Dudek, C. Angelucci, D. Pathiranage, P. Wang, V. Mallikarjun, C. Lawless, J. Swift, K.E. Kadler, R.P. Boot-Handford, J.A. Hoyland, S.R. Lamande, J.F. Bateman, Q.J. Meng, Circadian time series proteomics reveals daily dynamics in cartilage physiology, Osteoarthritis Cartilage 29(5) (2021) 739749.

[30] T.A. LeGates, C.M. Altimus, H. Wang, H.K. Lee, S. Yang, H. Zhao, A. Kirkwood, E.T. Weber, S. Hattar, Aberrant light directly impairs mood and learning through melanopsin-expressing neurons, Nature 491(7425) (2012) 594-8.

[31] M. Izumo, M. Pejchal, A.C. Schook, R.P. Lange, J.A. Walisser, T.R. Sato, X. Wang, C.A. Bradfield, J.S. Takahashi, Differential effects of light and feeding on circadian organization of peripheral clocks in a forebrain Bmal1 mutant, Elife 3 (2014).

[32] G. Du, L. Li, X. Zhang, J. Liu, J. Hao, J. Zhu, H. Wu, W. Chen, Q. Zhang, Roles of TRPV4 and piezo channels in stretch-evoked $\mathrm{Ca}(2+)$ response in chondrocytes, Exp Biol Med (Maywood) 245(3) (2020) 180-189.

[33] C. Matta, T. Juhasz, Z. Szijgyarto, B. Kolozsvari, C. Somogyi, G. Nagy, P. Gergely, R. Zakany, PKCdelta is a positive regulator of chondrogenesis in chicken high density micromass cell cultures, Biochimie 93(2) (2011) 149-59.

[34] X. Song, H. Hu, M. Zhao, T. Ma, L. Gao, Prospects of circadian clock in joint cartilage development, FASEB J 34(11) (2020) 14120-14135. 